\title{
Effect of COVID-19 on the mental health of young adults in India
}

\author{
Yavana Rani Subramanian, Vipul Sharma* \\ CMS Business School, Jain University, Bengaluru, Karnataka, India \\ *Correspondence E-mail: vipuls98@gmail.com
}

\begin{abstract}
Background: COVID-19 pandemic is devasting for human health. Apart from physical health COVID19 has affected mental health also. This study examines how COVID-19 pandemic has affected the mental health especially in young adults in India. Methods: A one-time Online Questionnaire Survey was completed between the age of 18 to 30 years and form was randomly circulated across India (with the help of friends and family). Results: Overall, three-fourth of participants were worried about the COVID-19 pandemic where female had more fear, sadness and nightmares than male. Also, mental health is stigma in our society. Conclusion: Findings highlight the impact of COVID-19 on the mental health of young adults in India.
\end{abstract}

Keywords: COVID-19; Coronavirus; Mental Health; Young Adults; Mental Health in India

\section{Introduction}

COVID-19 pandemic has created a disturbed situation in the well-being of people all over the world. Many people have lost their job, many have lost their life, and many are still struggling for life. Pandemic has created a self-trauma for many people.

COVID-19 has locked the whole world. India is famous for its diverse culture, religion and festivals but due to the pandemic all the festivals were dropped, all the social gatherings stopped, schools and colleges were shut down and, on this date, everything is starting to open at a slow pace. This shut down has created a long distance between human, people can't go out can't talk with their loved one's face to face and also missing all the life fun. Although these were necessary to stop the spread, but these can be the factor of rise in stress and anxiety. In March 2020, an America representative survey found that $31 \%$ of adults were very or extremely worried about becoming infected with COVID-19, representing a $45 \%$ increase from polls conducted only a month earlier (The Associated Press-NORC Center for Public Affairs Research, 2021). Even the hoax news circulated about Corona virus on social media made people uneasy and sad (van Der Linden, Roozenbeek \& Compton, 2020) Hearing the word Quarantine itself creates an anxiety and facing that situation is even worse. Developing negative emotions, thoughts, concerns about family health and economic crisis attracted stress for common people. Similarly, as people see and hear the news from media about deaths due to the pandemic, people suffer.

Due to rising cases and lockdown in India, many people created a cage in their mind which trapped only negative thoughts and caused disrupt sleep and insomnia and also lead to some serious mental health problems like Depression, Anxiety and Stress (Singh et 
al., 2020). This study mainly focuses on the impact of COVID-19 pandemic on the mental

\section{Review of Literature:}

According to the PubMed database, early evidence suggests that symptoms of anxiety and depression ranging $16-28 \%$ and selfreported stress ranging $0-8 \%$ are frequent psychological reactions to the COVID-19 pandemic and may be linked with disturbed sleep (Holmes et al., 2020). Wang et al. (2020) studied the general population in China through Online Survey to find out the immediate psychological responses and associated factors during the initial stage COVID-19 disease and they found out that $16.5 \%$ showed moderate to severe depressive symptoms, $28.8 \%$ showed moderate to severe anxiety symptoms and $8.1 \%$ showed moderate to severe stress.

Xiao et al. (2020) studied the individuals in self-isolation for 14 days in China through cross-sectional, self-rated questionnaire and found out that mean anxiety score was $55.4 \pm$ 14.3 which meant that Anxiety positively correlated with stress and negatively with

\section{Methodology:}

Young adults in India are silently suffering from these mental issues. In India mental health issues are taken as myth and most of the people hesitate to open up about this. Issue like mental health is stigma in our society. People fear that these issues will be joke for others and won't understand their situation as if it is a taboo. With the rising cases of COVID19 in India, there is also increase in the mental health problems.

The main purpose of this research is to understand how the COVID-19 pandemic is impacting our mental health. This research is only for the young adults (18 -30) in India who are vulnerable to these issues.

\section{Results and Discussion:}

This study contributes to limited research examining the impact of COVID-19 on the mental health of young adults, general population between the ages of 18-30 from different regions in India. Findings from general population of young adults COVID-19 health of young adults in India.

sleep quality and social capital (Xiao et al., 2020). Social capital positively correlated with sleep quality. According to the conducted in mainland China to explore the cognition, psychological state, anxiety and depression level of students in during the 2019 pandemic year found out that out of 509 students, majority of them strongly agreed to reduce going out and gathering and anxiety and depression levels increased during the pandemic. About $24.9 \%$ of students experienced anxiety due to the pandemic. A report from National Health Service (NHS) of England published that the rate of prescribing anti-depressant during COVID-19 lockdown in UK increased significantly and the data suggested that the predictions about mental health would be severely affected by COVID19 was correct (Armitage, 2021). However, similar assessments have not been conducted in India especially for the people between the ages of 18 to $30 \mathrm{yrs}$.

This research is designed to assess the hypothesis that COVID-19 has any impact on the mental health of young adults in India or not. A Survey research design used for general population in India between the ages of 18 to 30 years (Richardson et al., 2010; Russell, Peplau \& Cutrona, 1980; Spitzer et al., 2006; The Associated Press-NORC Center for Public Affairs Research, 2021).

In this research, primary data collection has been done through Online Survey by using Google Form and general population of India are taken as a variable that falls in the age group of $18-30$.

survey in India indicates that $83.8 \%$ were worried about COVID-19 pandemic (Richardson et al., 2010). 77.8\% were worried about someone in their family might get infected. $70.9 \%$ had fear of going out. Even, 9.4\% didn't feel safe inside their home which shows that this pandemic has affected really bad. $93.2 \%$ don't feel safe in public areas. 
Table 1: Questions for all Responder ( $N=117)$

\begin{tabular}{|c|c|c|}
\hline Variable & $\mathbf{N}$ & $\%$ \\
\hline \multicolumn{3}{|l|}{ Are you worried about COVID-19 pandemic? } \\
\hline Yes & 98 & 83.8 \\
\hline No & 11 & 9.4 \\
\hline Maybe & 8 & 6.8 \\
\hline \multicolumn{3}{|l|}{ Are you worried about someone in your family might get infected? } \\
\hline Yes & 91 & 77.8 \\
\hline No & 18 & 15.4 \\
\hline Maybe & 8 & 6.8 \\
\hline \multicolumn{3}{|l|}{ Have you been infected by COVID-19? } \\
\hline Yes & 92 & 78.6 \\
\hline No & 25 & 21.4 \\
\hline \multicolumn{3}{|l|}{ Has anyone in your family / close friend been infected? } \\
\hline Yes & 92 & 78.6 \\
\hline No & 25 & 21.4 \\
\hline \multicolumn{3}{|l|}{ Do you fear of going out? } \\
\hline Yes & 83 & 70.9 \\
\hline No & 34 & 29.1 \\
\hline \multicolumn{3}{|l|}{ Do you feel safe inside your home? } \\
\hline Yes & 106 & 90.6 \\
\hline No & 11 & 9.4 \\
\hline \multicolumn{3}{|l|}{ Do you feel safe in public areas? } \\
\hline Yes & 8 & 6.8 \\
\hline No & 109 & 93.2 \\
\hline \multicolumn{3}{|l|}{$\begin{array}{l}\text { In the past pandemic year, how often you had the feelings of fear, sadness, or } \\
\text { worry? }\end{array}$} \\
\hline Very Often & 33 & 28.2 \\
\hline Often & 25 & 21.4 \\
\hline Sometimes & 45 & 38.5 \\
\hline Rarely & 10 & 8.5 \\
\hline Never & 4 & 3.4 \\
\hline \multicolumn{3}{|l|}{ In the past pandemic year, how often you had difficulty sleeping or nightmares? } \\
\hline Very Often & 21 & 17.9 \\
\hline Often & 15 & 12.8 \\
\hline Sometimes & 27 & 23.1 \\
\hline Rarely & 26 & 22.2 \\
\hline Never & 28 & 23.9 \\
\hline \multicolumn{3}{|l|}{$\begin{array}{l}\text { In the past pandemic year, how often you had physical reactions, such as } \\
\text { headaches, body pains, and stomach problems? }\end{array}$} \\
\hline Very Often & 12 & 10.3 \\
\hline Often & 16 & 13.7 \\
\hline Sometimes & 37 & 31.6 \\
\hline Rarely & 38 & 32.5 \\
\hline Never & 14 & 12 \\
\hline
\end{tabular}


Asia-Pacific J.Mgmt. Tech. Volume 2(3) 17-25

\begin{tabular}{|c|c|c|}
\hline \multicolumn{3}{|l|}{ In the past pandemic year, how often you had Panic attacks? } \\
\hline Very Often & 4 & 3.4 \\
\hline Often & 11 & 9.4 \\
\hline Sometimes & 16 & 13.7 \\
\hline Rarely & 32 & 27.4 \\
\hline Never & 54 & 46.2 \\
\hline \multicolumn{3}{|l|}{ How are you dealing with the financial impact of the pandemic? } \\
\hline Very Unhappy & 32 & 27.4 \\
\hline Unhappy & 22 & 18.8 \\
\hline Ok & 51 & 43.6 \\
\hline Happy & 8 & 6.8 \\
\hline Very Happy & 4 & 3.4 \\
\hline \multicolumn{3}{|l|}{ Has Lockdown impacted you? } \\
\hline Extremely & 54 & 46.2 \\
\hline Somewhat & 57 & 48.7 \\
\hline Not at all & 6 & 5.1 \\
\hline \multicolumn{3}{|c|}{$\begin{array}{l}\text { If it happens to face the situation of Home-Isolation or Quarantine, how worried } \\
\text { you will be? }\end{array}$} \\
\hline Extremely & 46 & 39.3 \\
\hline Somewhat & 55 & 47 \\
\hline Not at all & 16 & 13.7 \\
\hline \multicolumn{3}{|c|}{$\begin{array}{l}\text { Did you already have any kind of problems mentioned above before the } \\
\text { Pandemic? }\end{array}$} \\
\hline Yes & 38 & 32.5 \\
\hline No & 79 & 67.5 \\
\hline \multicolumn{3}{|c|}{ How are you managing the above problems, if any, during COVID-19? } \\
\hline Yoga/Meditation & 32 & 27.4 \\
\hline Cooking & 42 & 35.9 \\
\hline Social Media & 76 & 65 \\
\hline Watching TV/movies & 73 & 62.4 \\
\hline Physical Activity & 58 & 49.6 \\
\hline Reading Books & 42 & 35.9 \\
\hline Listening to Music & 73 & 62.4 \\
\hline Workout & 1 & 0.9 \\
\hline Work and Study & 1 & 0.9 \\
\hline Dance & 1 & 0.9 \\
\hline Stay connected with my family & 1 & 0.9 \\
\hline Doing new works & 1 & 0.9 \\
\hline Painting and drawing and sketching & 1 & 0.9 \\
\hline Finding opportunities to work and learn new something & 1 & 0.9 \\
\hline Gaming & 1 & 0.9 \\
\hline I don't have any medical issues, cold, headache will be usual & 1 & 0.9 \\
\hline Socialising with the family more. & 1 & 0.9 \\
\hline \multicolumn{3}{|l|}{ Do you think you can handle this Situation? } \\
\hline Yes & 58 & 49.6 \\
\hline No & 9 & 7.7 \\
\hline Maybe & 50 & 42.7 \\
\hline
\end{tabular}




\begin{tabular}{|l|c|c|}
\hline Do you think talking about mental health is stigma in our society? & & \\
\hline Yes & 60 & 51.3 \\
\hline No & 27 & 23.1 \\
\hline Maybe & 30 & 25.6 \\
\hline Do you over think? & & \\
\hline Yes & 48 & 41 \\
\hline No & 26 & 22.2 \\
\hline Sometimes & 43 & 36.8 \\
\hline
\end{tabular}

However, the above findings are very common for everyone and it's very natural to be worried, but the next few findings show the effects of pandemic caused by COVID- 19 . $10.3 \%$ and $13.7 \%$ of respondents had physical reactions such as headaches, body pains, and stomach problems very often and often respectively. $3.4 \%$ and $9.4 \%$ of respondents had panic attack very often and often respectively (Richardson et al., 2010).

COVID-19 pandemic has also affected the financial conditions of people in India. The survey suggests that $27.4 \%$ and $18.8 \%$ of the respondents were very unhappy and unhappy respectively with the financial conditions created by the COVID-19 pandemic.

Mental illness stigma is one of the major issues in India (Venkatesh et al., 2015). People don't receive adequate mental health care and treatment as required and people don't open up about it thinking society won't accept it. The above findings also prove the previous statement as $51.3 \%$ of the respondents think that talking about mental health is stigma in our society.

Lockdown and Quarantine also has some adverse effect on the mental health (Russell, Peplau \& Cutrona, 1980). Lockdown creates a distance from your friends and relative, it keeps you away from travelling to your favorite places, so it does have an impact on everyone (Loades et al., 2020). The findings suggest

Table 2: Questions Stratified by Gender that $46.2 \%$ of the respondents were extremely impacted by the lockdown.

In the same way as lockdown, but its upgraded version is Quarantine in which you are not only away from your friends and relatives but also away from your family and sometimes from your own house. Many are afraid just by listening to the word quarantine, lots of questions arises in the mind when someone is asked to move to an unknown place for 14 days (Brooks et al., 2020). Rich people may get all their facilities in the quarantine center, but common man does get a proper food will be a question revolving in the minds of every ordinary person. The above statement is justified by the survey which indicates that $39.3 \%$ of the respondents were extremely worried to face the situation of home-isolation or quarantine.

Young adults in India mainly are students and working people and they already have lots of pressure of work and studies. Adding pandemic in their life is just like overloading problems with a pinch of anxiety and stress (Aarons et al., 2008). People who never knew about mental health issues got a great knowledge during the pandemic and people who never had any of this problem also started to get some of it. Findings indicate that $67.5 \%$ of respondents never had any kind of mental health problems before the pandemic and $7.7 \%$ of respondents were not able to handle this pandemic situation.

\begin{tabular}{|l|l|l|l|l|l|}
\hline Variable & Male (N=59) & $\begin{array}{l}\text { Female } \\
\mathbf{( N = 5 8 )}\end{array}$ & $\begin{array}{l}\text { Chi-Square } \\
\text { Statistics }\end{array}$ & p-Value & Interpretation \\
\hline Are you worried about COVID-19 pandemic? & & & & \\
\hline Yes & 48 & 50 & 0.85 & 0.654 & $\begin{array}{l}\text { No significant } \\
\text { association. }\end{array}$ \\
\hline No & 7 & 4 & & & \\
\hline
\end{tabular}


Asia-Pacific J.Mgmt. Tech. Volume 2(3) 17-25

\begin{tabular}{|c|c|c|c|c|c|}
\hline Maybe & 4 & 4 & & & $\begin{array}{l}\text { It accepts the Null } \\
\text { Hypothesis }\end{array}$ \\
\hline \multicolumn{6}{|c|}{ Are you worried about someone in your family might get infected? } \\
\hline Yes & 44 & 47 & \multirow{3}{*}{2.591} & \multirow{3}{*}{0.274} & \multirow{3}{*}{$\begin{array}{l}\text { No significant } \\
\text { association. } \\
\text { It accepts the Null } \\
\text { Hypothesis }\end{array}$} \\
\hline No & 12 & 6 & & & \\
\hline Maybe & 3 & 5 & & & \\
\hline \multicolumn{6}{|c|}{ Have you been infected by COVID-19? } \\
\hline Yes & 10 & 15 & \multirow[b]{2}{*}{1.383} & \multirow[b]{2}{*}{0.24} & \multirow{2}{*}{$\begin{array}{l}\text { No significant } \\
\text { association. } \\
\text { It accepts the Null } \\
\text { Hypothesis }\end{array}$} \\
\hline No & 49 & 43 & & & \\
\hline \multicolumn{6}{|c|}{ Do you feel safe in public area } \\
\hline Yes & 4 & 4 & \multirow[b]{2}{*}{0.001} & \multirow[b]{2}{*}{0.98} & \multirow{2}{*}{$\begin{array}{l}\text { No significant } \\
\text { association. } \\
\text { It accepts the Null } \\
\text { Hypothesis }\end{array}$} \\
\hline No & 55 & 54 & & & \\
\hline \multicolumn{6}{|c|}{ In the past pandemic year, how often you had the feelings of fear, sadness, or worry? } \\
\hline Very Often & 10 & 23 & \multirow{5}{*}{10.762} & \multirow{5}{*}{0.029} & \multirow{5}{*}{$\begin{array}{l}\text { Significant } \\
\text { Association. } \\
\text { It rejects Null } \\
\text { Hypothesis and } \\
\text { accepts Alternate } \\
\text { Hypothesis }\end{array}$} \\
\hline Often & 11 & 14 & & & \\
\hline Sometimes & 28 & 17 & & & \\
\hline Rarely & 7 & 3 & & & \\
\hline Never & 3 & 1 & & & \\
\hline \multicolumn{6}{|c|}{ In the past pandemic year, how often you had difficulty sleeping or nightmares? } \\
\hline Very Often & 9 & 12 & \multirow{5}{*}{18.319} & \multirow{5}{*}{0.001} & \multirow{5}{*}{$\begin{array}{l}\text { Significant } \\
\text { Association. } \\
\text { It rejects Null } \\
\text { Hypothesis and } \\
\text { accepts Alternate } \\
\text { Hypothesis }\end{array}$} \\
\hline Often & 7 & 8 & & & \\
\hline Sometimes & 7 & 20 & & & \\
\hline Rarely & 13 & 13 & & & \\
\hline Never & 23 & 5 & & & \\
\hline \multicolumn{6}{|c|}{$\begin{array}{l}\text { In the past pandemic year, how often you had physical reactions, such as headaches, body pains, and } \\
\text { stomach problems? }\end{array}$} \\
\hline Very Often & 2 & 10 & \multirow{5}{*}{9.77} & \multirow{5}{*}{0.044} & \multirow{5}{*}{$\begin{array}{l}\text { Significant } \\
\text { Association. } \\
\text { It rejects Null } \\
\text { Hypothesis and } \\
\text { accepts Alternate } \\
\text { Hypothesis }\end{array}$} \\
\hline Often & 9 & 7 & & & \\
\hline Sometimes & 16 & 21 & & & \\
\hline Rarely & 22 & 16 & & & \\
\hline Never & 10 & 4 & & & \\
\hline \multicolumn{6}{|c|}{ In the past pandemic year, how often you had Panic attacks? } \\
\hline Very Often & 0 & 4 & & & Significant \\
\hline Often & 5 & 6 & & & Association. \\
\hline Sometimes & 5 & 11 & 10088 & 0039 & It rejects \\
\hline Rarely & 15 & 17 & 10.000 & 0.039 & Hypothesis and \\
\hline Never & 34 & 20 & & & $\begin{array}{l}\text { accepts Alternate } \\
\text { Hypothesis }\end{array}$ \\
\hline How are you d & inan & e pan & & & \\
\hline Very Unhappy & 11 & 21 & & & Significant \\
\hline Unhappy & 16 & 6 & & & Association. \\
\hline Ok & 24 & 27 & 9839 & 0,043 & It rejects \\
\hline Happy & 6 & 2 & (5.00 & 0.040 & Hypothesis and \\
\hline Very Happy & 2 & 2 & & & $\begin{array}{l}\text { accepts Alternate } \\
\text { Hypothesis }\end{array}$ \\
\hline $\begin{array}{l}\text { Has Lockdov } \\
\text { you? }\end{array}$ & & & & & \\
\hline Extremely & 26 & 28 & 0.223 & 0.894 & significant \\
\hline
\end{tabular}




\begin{tabular}{|c|c|c|c|c|c|}
\hline Somewhat & 30 & 27 & & & \multirow{2}{*}{$\begin{array}{l}\text { association. } \\
\text { It accepts the Null } \\
\text { Hypothesis }\end{array}$} \\
\hline Not at all & 3 & 3 & & & \\
\hline \multicolumn{6}{|c|}{ If it happens to face the situation of Home-Isolation or Quarantine, how worried you will be? } \\
\hline Extremely & 24 & 22 & \multirow{3}{*}{1.242} & \multirow{3}{*}{0.537} & \multirow{3}{*}{$\begin{array}{l}\text { No significant } \\
\text { association. } \\
\text { It accepts the Null } \\
\text { Hypothesis }\end{array}$} \\
\hline Somewhat & 29 & 26 & & & \\
\hline Not at all & 6 & 10 & & & \\
\hline \multicolumn{6}{|c|}{ Did you already have any kind of problems mentioned above before the Pandemic? } \\
\hline Yes & 12 & 26 & & & \multirow{2}{*}{ 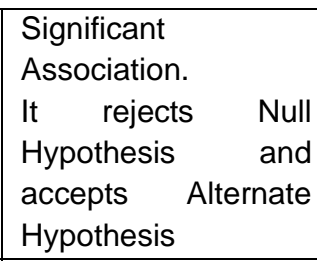 } \\
\hline No & 47 & 32 & 7.998 & 0.005 & \\
\hline \multicolumn{6}{|c|}{ Do you think talking about mental health is stigma in our society? } \\
\hline Yes & 24 & 36 & & & \multirow{3}{*}{$\begin{array}{l}\text { Significant } \\
\text { Association. } \\
\text { It rejects Null } \\
\text { Hypothesis and } \\
\text { accepts Alternate } \\
\text { Hypothesis }\end{array}$} \\
\hline No & 15 & 12 & & & \\
\hline Maybe & 20 & 10 & 6.059 & 0.048 & \\
\hline \multicolumn{6}{|c|}{ Do you over think? } \\
\hline Yes & 25 & 23 & & & \multirow{3}{*}{ 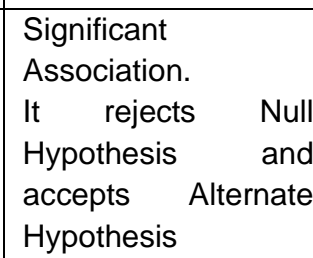 } \\
\hline No & 18 & 8 & & & \\
\hline Sometimes & 16 & 27 & 6.735 & 0.034 & \\
\hline
\end{tabular}

This study contributes to the active, limited research examining the impact of COVID-19 on young adults, particularly through finding the differences by gender. There was a significant association in the feelings of fear, sadness, and difficulty sleeping which means that gender is dependent on these situations. Females are in greater risk for psychological problem than males (Hou et al., 2020). Female had more fear, sadness and nightmares than male. Not only the mental reactions but physical reactions like headaches, body pains and stomach problem were seen more in female than male. Panic attacks were also seen more in female. These findings also indicate that there was a significant association between financial impact of the pandemic and gender. Females were unhappy with financial condition during pandemic than male. For some people, mental health issue may have risen due to this pandemic, but this study shows that mental health problems were seen in both the gender before the pandemic in which female were more than male.

\section{Conclusion}

The conclusion from this finding indicates that the effect of pandemic on the mental health is more in female than male. More concern should be emphasized on the women of this country. People hesitate to open up about their mental condition especially in India so programs regarding mental health should be developed in future. Platforms and opportunities should be provided to open up about the conditions and their issues. More concern regarding mental health should be given in the medical field. Many activities should be programmed to overcome the stigma of mental health. Several awareness programs should be started to spread the understanding of mental health problems. Therapy sessions and live interactions should be motivated in India. Mental health problems should be treated just like any other health disease without any disclosure. As soon as we start to open about the mental health and start talking about it, half of the mental illness will be reduced automatically. 


\section{Acknowledgments:}

The successful completion of any task would be incomplete without mentioning the names of people who helped to make it possible. The authors take this opportunity to express their gratitude towards everyone who supported them throughout this research.

The authors are very glad to express their gratitude to Dinesh Nikant, Academic Dean, CMS Business School, (Jain, deemed-to-be University), Bangalore for giving me this

\section{References}

Aarons, G. A., Monn, A. R., Leslie, L. K., Garland, A. F., Lugo, L., Hough, R. L., \& Brown, S. A. (2008). Association between mental and physical health problems in highrisk adolescents: A longitudinal study. Journal of Adolescent Health, 43(3), 260-267.

Armitage, R. (2021). Antidepressants, primary care, and adult mental health services in England during COVID-19. The Lancet Psychiatry, 8(2), e3.

Brooks, S. K., Webster, R. K., Smith, L. E., Woodland, L., Wessely, S., Greenberg, N., \& Rubin, G. J. (2020). The Lpsychological impact of quarantine and how to reduce it: rapid review of the evidence. The Lancet, 395(10227), 912-920.

Holmes, E. A., O'Connor, R. C., Perry, V. H., Tracey, I., Wessely, S., Arseneault, L., ... \& Bullmore, E. (2020). Multidisciplinary research priorities for the COVID-19 pandemic: a call for action for mental health science. The Lancet Psychiatry, 7(6), 547-560.

Hou, F., Bi, F., Jiao, R., Luo, D., \& Song, K. (2020). Gender differences of depression and anxiety among social media users during the COVID-19 outbreak in China: a cross-sectional study. BMC Public Health, 20(1), 1-11.

Loades, M. E., Chatburn, E., Higson-Sweeney, N., Reynolds, S., Shafran, R., Brigden, A., ... \& Crawley, E. (2020). Rapid systematic review: the impact of social isolation and loneliness on the mental health of children and adolescents in the context of COVID-19. Journal of the American Academy of Child \& Adolescent Psychiatry, 59(11), 1218-1239.

Richardson, L. P., Rockhill, C., Russo, J. E., Grossman, D. C., Richards, J., McCarty, C., ... \& Katon, W. (2010). Evaluation of the PHQ-2 opportunity. Also, they would like to thank Dr. Rupesh Sinha, CMS Business School, (Jain, deemed-to-be University) for his guidance and suggestions.

They would also like to thank each and every one who participated in the questionnaire created by them for this research and without the help of participants their research would have been incomplete.

\section{Conflict of Interest:}

Conflict of Interest is declared none.

as a brief screen for detecting major depression among adolescents. Pediatrics, 125(5), e1097-e1103. Russell, D., Peplau, L. A., \& Cutrona, C. E. (1980). The revised UCLA Loneliness Scale: concurrent and discriminant validity evidence. Journal of Personality and Social Psychology, 39(3), 472.

Singh, S., Roy, M. D., Sinha, C. P. T. M. K., Parveen, C. P. T. M. S., Sharma, C. P. T. G., \& Joshi, C. P. T. G. (2020). Impact of COVID19 and lockdown on mental health of children and adolescents: A narrative review with recommendations. Psychiatry Research, 113429.

Spitzer, R. L., Kroenke, K., Williams, J. B., \& Löwe, B. (2006). A brief measure for assessing generalized anxiety disorder: the GAD-7. Archives of Internal Medicine, 166(10), 1092-1097.

The Associated Press-NORC Center for Public Affairs Research (2021). Worries about the coronavirus increase. $27^{\text {th }}$ January. https://www.norc.org/NewsEventsPublications/ PressReleases/Pages/worries-about-thecoronavirus-increase.aspx van Der Linden, S., Roozenbeek, J., \& Compton, J. (2020). Inoculating against fake news about COVID-19. Frontiers in Psychology, 11, 2928.

Venkatesh, B. T., Andrews, T., Mayya, S. S., Singh, M. M., \& Parsekar, S. S. (2015). Perception of stigma toward mental illness in South India. Journal of Family Medicine and Primary Care, 4(3), 449.

Wang, C., Pan, R., Wan, X., Tan, Y., Xu, L., Ho, C. S., \& Ho, R. C. (2020). Immediate psychological responses and associated factors during the initial stage of the 2019 
Asia-Pacific J.Mgmt. Tech. Volume 2(3) 17-25

coronavirus disease (COVID-19) epidemic among the general population in China. International Journal of Environmental Research and Public Health, 17(5), 1729.

Xiao, H., Zhang, Y., Kong, D., Li, S., \& Yang, N. (2020). Social capital and sleep quality in individuals who self-isolated for 14 days during the coronavirus disease 2019 (COVID-19) outbreak in January 2020 in China. Medical Science Monitor: International Medical Journal of Experimental and Clinical Research, 26, e923921-1. 